Peer-Reviewed Article

ISSN: 2162-3104 Print/ ISSN: 2166-3750 Online

Volume 5, Issue 2 (2015), pp.143-160

(C) Journal of International Students

http://jistudents.org

\title{
Meeting the Needs of Chinese English Language Learners at Writing Centers in America: A Proposed Culturally Responsive Model
}

\author{
Peizhen Wang (Doctoral Student) \\ Crystal Machado, EdD \\ Department of Professional Studies in Education \\ Indiana University of Pennsylvania (USA)
}

\begin{abstract}
This paper describes the ways in which Writing Centers (WC) currently serve English Language Learners (ELL) at American universities. The authors argue that the pedagogy offered at these centers does not always meet the needs of the Chinese ELLs who make up the largest population of ELLs at American universities. The proposed supplemental model they recommend, which is grounded in Culturally Responsive Pedagogy (CRP), has the potential to better meet the needs of Chinese ELLs. The authors identify obstacles to successful implementation of the proposed model and ways in which these, and gaps in research, can be addressed by directors of Writing Centers.
\end{abstract}

Keywords: Chinese, English Language Learners, Writing Centers, Culturally Responsive Pedagogy, Culturally Responsive Teaching, Program Evaluation

Academic writing is a significant part of students' academic learning and is difficult for a large majority of native speakers of English (NSE); but it is even more so for international students who are often English Language Learners (ELL). With the large influx of international students at American universities, higher education faculty, researchers, and administrators need to address this growing minority's needs, particularly in their social and academic lives. The extent to which writing centers (WC), which were developed to meet the needs of NSE, meet the needs of a population that now includes many more local and international ELLs should be examined.

This paper will first provide readers with an overview of the changing demographics in American higher education. It will focus on Chinese ELLs' experiences with WC, primarily because Chinese students comprise the largest group of international students at American universities, and also because the lead author, a Chinese ELL herself, has had personal experiences with both WC and the students they serve. Following a description of the cultural differences between Chinese and American students and the related influence on academic writing, the paper will describe challenges faced by Chinese ELLs at WCs. The paper will then explain how some of these challenges can be mitigated by using Culturally Responsive 
Pedagogy (CRP) as a guiding theory to inform the philosophy, programming, and tutor-tutee interactions that take place at the WC. Finally, the paper will identify obstacles to successful implementation of the proposed program, as well as ways in which these obstacles, and gaps in research, can be addressed by directors of Writing Centers.

\section{Changing Demographics in the Higher Education Classrooms of America}

The student body of American schools has become increasingly diverse, culturally and linguistically, due to the growing numbers of immigrants from all over the world (Banks, 2010; de Araujo, 2011; Harklau, Losey, \& Siegal, 1999; Matsuda, Fruit, \& Lamm, 2006), including countries in Asia, the Middle East, and Africa; this has resulted in an increase in bilingual and multilingual learners in college classrooms. American colleges and universities educate 40 percent more international students than a decade ago. The seven percent increase last year resulted in a record high of 819,644 international students (Open Doors Report, 2013). The 55,000 increase from 2011/2012 includes proportionately more students from Saudi Arabia and China. With a 21 percent increase in Chinese students the Chinese international student population has soared to 235,000 students (Open Doors Report, 2013).

Andrade (2006) found that international students, compared to their American counterparts, have limited access to social and emotional support from family and friends, especially in the early stages of their college lives. Additionally, studies show that international students' social and academic adjustment in American colleges and universities could be negatively influenced due to limited proficiency in English (Andrade, 2006; de Araujo, 2011; Senyshyn, Warford, \& Zhan, 2000). In recent years, the New York Times and The Chronicle of Higher Education have been urging institutions of higher education to address the challenges faced by Chinese students studying in America (Bartlett \& Fischer, 2011; Fischer, 2013). To provide Chinese students with the support they need to gain proficiency in spoken and written English, it is essential that educators and directors of WCs understand how their needs differ from those of their American counterparts.

\section{Chinese English Language Learners' Needs}

Academic language, both oral and written, is a fundamental requirement for college students. Because academic language includes formal speaking, comprehending, and writing, it is not acquired as easily as conversational language (Rodriguez \& Gomez, 2008). Academic writing is one of the basic skills that leads to academic achievement and future success in students' professions (Elander, Harrington, Norton, Robinson, \& Reddy, 2006; Salamonson, Koch, Weaver, Everett, \& Jackson, 2010; Weaver \& Jackson, 2011). Academic writing competence is essential for people who need to communicate socially and professionally (Yu \& He, 2010). Weaver and Jackson (2011) found that writing is difficult for most students, regardless of their background. Students who speak English as a second or third language face additional challenges as they try to master critical skills (Kasper, 1997; Mohan \& Lo, 1985; Salamonson, Everett, Koch, Andrew, \& Davidson, 2008; Zhang, 2008). Shei (2005), who studied 15 Chinese graduate students, recommends additional research to examine the factors that contribute to excellence in Chinese ELLs' academic writing.

$\mathrm{Yu}$ and $\mathrm{He}$ (2010) emphasize the importance of understanding the factors that influence thinking, which is the basis of good writing. More than two decades ago, Cai (1993) and Fox 
(1994) found that the primary obstacles hindering clear expressions in academic writing are cultural factors that influence ways of thinking, and not factors related to low English proficiency. Research by Huang and Brown (2009) and Li (2007) confirms that cultural differences continue to explain the limitations of Chinese ELLs' writing. A lack of awareness about Chinese students' rhetorical habits, which come from their cultural and ideological backgrounds, could result in the belief that Chinese students produce "bad writing" (Cai, 1993). A deeper understanding of how people of diverse backgrounds think will make it easier to tailor services to their needs.

Nisbett, Peng, Choi, and Norenzayan (2001) found that people growing up in diverse cultural backgrounds have different ways of thinking. Triandis's (1980) groundbreaking book on subjective culture, the first Handbook of Cross-Cultural Psychology, and Hofstede's (1980) highly influential book, Culture's Consequences, led to an explosion of cross-cultural research in the field of psychology that explores the constructs of individualism and collectivism and the ways in which these constructs explain cultural differences. Hofstede found four dimensions of cultural differences between nations. He found that people raised in modern developed nations (e.g., the United States, Canada, and the Netherlands) had higher levels of individualism than those in traditional, developing nations (e.g., Guatemala, Pakistan, and Thailand), who had higher levels of collectivism. American students, who tend to have an individualist orientation, value individual freedom, personal success, and self-expression; conversely, people with a collectivistic orientation, like many Chinese international students, value relationships, group harmony, and group success (Donkor, 2011). More recently, Williams (2011), who studied helpseeking and self-efficacy behavior in 671 undergraduates measured by frequency of WC visitations, found that ELL students were more active help-seekers than their domestic counterparts. They speculated that this was due to ELLs' attribution tendencies; research documents that Asian students are more likely to attribute academic success to internal and controllable factors than American students.

Additionally, the differences in the ways students perceive the world are further shaped by the types of education they receive. The education that American students receive is typically based on the belief that students are innately curious about the world, eager to explore, and favor originality in learning (Ballard \& Clanchy, 1991; J. Li, 2011; Nisbett et al., 2001). Students raised in America, on average, have had the opportunity to experience a classroom environment that encourages critical thinking, questioning, group discussions, peer review, and independent thinking. As such, American students tend to think analytically, and this is reflected both in speaking and in writing. However, students raised in China, who are influenced by Confucian and Taoist philosophies, tend to think holistically and are not encouraged to question the teachers' authority (Eckstein, Kalaydjian, Miranda, Mitchell, Mohamed, Smith-Palinkas, York, \& Zollner, 2003).

The standardized test-based educational system Chinese students experience encourages rote memorization ( $\mathrm{Li}, 2011$; Li, 2007; Wen, 2006). Very seldom are students encouraged to question ideas in textbooks and scholarly articles. Students are expected to give thoughtful answers instead of personal or unstructured answers (Cortazzi \& Jin, 1996). Scholars have found that Chinese students perceive peer review or peer feedback to be an ineffective way of learning, because critique has the potential to disrupt group relationships and group harmony, which they value greatly (Carson \& Nelson, 1996; X. Li, 2007). How effectively are the unique needs of Chinese ELLs met when they move from China to America? 


\section{Writing Centers in America: Is Anything Missing?}

This section provides an overview of the services provided by American universities to help students improve their use of academic language and a description of the challenges faced by Chinese ELLs who frequent writing centers.

\section{Services Provided by American Writing Centers}

WCs were initially developed to meet the needs of NSEs in the 1970s in response to the literacy crisis. As the student bodies at American universities started to become ethnically and linguistically diverse, WCs started to serve increasing numbers of local and international ELLs. WCs play an important role in the academic lives of American and international students by providing academic writing support for college students across disciplines. They help students become accomplished writers in course assignments or other writing-intensive tasks by offering one-on-one tutoring, workshops, etc. (Mahaffy, 2007). The primary focus of WCs tends to be on students' rhetorical writing, such as organization and coherence, which are non-linguistic and aimed at higher-order thinking (Nakamaru, 2010; Wang, 2012).

Only 3\% of 4-year public universities employed professional tutors with advanced degrees (Writing Center Research Report, 2007-2008). Peer tutoring has gained popularity in WCs over the last couple of decades, largely because of the widely held perception that having similar experiences helps tutors to interact and communicate more effectively with tutees who come for help (Williams \& Severino, 2004). Tutors are typically peer students who have strong English writing skills and comprehensive knowledge about the English language.

Historically, WCs have been marginalized in the academy. Carino (2002), through analysis of the rhetoric of promotional materials and in-house correspondence from $20 \mathrm{WCs}$ at various 2- and 4-year institutions, found that WCs come under fire because outsiders assume that tutors write papers for students, which constitutes ethical misconduct. Others question the tutors' ability to meet the academic writing needs of disciplines that are very disparate (Carino, 2002). Rodby (2002) observed, through discussions with English Department tutors, that they were often leery of textual practices and values of other disciplines. Carino (2002) also observed that WCs employed a forceful rhetoric to help faculty recognize that WCs are places that supplement the work being done in traditional classrooms and not "grammar mills" (2002, p. 97).

The non-directive approach, which is favored by WCs across America, was challenged by Clark (1990) in her paper, Maintaining Chaos in the Writing Center: A Critical Perspective on Writing Center Dogma. Shamoon and Burns (1996) encouraged WCs to question the appropriateness of relying on one method to meet the needs of students that have diverse needs. They recommended a master-apprentice model that is grounded in methods that are more directive. The proposed supplemental program described in this paper illustrates how traditional and non-traditional approaches can be melded together to meet the needs of Chinese ELLs.

\section{Challenges Faced by Chinese English Language Learners at Writing Centers}

In 1984, Hawkins indicated that WCs were a "fertile ground for study" (p. xiv); more than a decade later, Murphy (1997) lamented the "absolute bankruptcy of writing center scholarship." While the increase in ELLs in K-12 American classrooms has led to an increase in research in the field of K-12 education, there is limited research that examines what needs to be 
done to support these students and international ELLs who come to America for undergraduate and graduate study. ELLs have not had the substantial English writing experiences that their American counterparts have had (Powers, 1993). They need help, not just with writing, but also with language learning (Nakamaru, 2010). Besides high-level thinking problems, such as content organization and rhetoric style, ELLs need assistance with sentence-level issues (Brendel, 2012; Nakamaru, 2010). There is a growing awareness, both at the institutional and program levels that people who work with ELLs need a comprehensive skill set. Unfortunately, ELLs do not always have access to second-language writing specialists, administrators, and instructors trained to provide service to diverse populations (Matsuda et al., 2006).

Scholars have begun to examine and describe the needs of English language writers, and the cultural challenges that American tutors face in responding to ELLs at the linguistic level (Nakamaru, 2010; Williams, 2002). The influence that American tutors at WCs have on ELLs' language learning is still being debated (Nakamaru, 2010). It is becoming apparent that strategies that work with native English speakers who visit WCs might not always meet the needs of multilingual learners. Since the 1990s, scholars have been discussing the ways in which tutorial strategies should be adjusted so that they are compatible with the ways in which multilingual writers think and learn (Williams \&Severino, 2004).

Using a qualitative method, Wang (2012) studied 16 dyads of student writers (ELLs) and tutor informants from WCs at two state universities in Pennsylvania and Ohio at both undergraduate and graduate levels. She found that ELLs' perspectives of tutoring pedagogy mismatched tutors' training and practice. Wang found that tutees, especially English language writers, regard student tutors as instructors and expect tutors to teach them how to write (Wang, 2012). Weigle and Nelson (2004) found that the tutors' roles depend on their backgrounds and tutees' English proficiency levels. The tutors at American WCs, who are often native English speakers, provide English-only tutoring, which might not be enough, especially for students with limited English proficiency (Wang, 2012). Tutors are typically trained to collaborate with tutees in Socratic ways (Thonus, 2004; Williams, 2002). They interact with their tutees by asking questions and giving advice; they then help them to find answers or solutions without being authorities. Research conducted over the last couple of decades suggests that American tutors do not always understand their tutees' needs. Thonus (2004) and Wang (2012) found that many do not feel confident enough to give their ELL tutees sufficient assistance. Additionally, Wang (2012) found that they do not feel responsible for English language writers' learning progress. She indicated that ELLs' academic needs would be better met if they had access to multilingual and multicultural facilities where they received instruction that aligns with their cultures.

\section{Could Culturally Responsive Pedagogy Address Some of the Challenges?}

The influence of culture on learning has been well documented in the literature (Gay, 2000, 2002; Roseberry, McIntyre, \& Gonzalez, 2001). Freeman and Freeman (2008) indicate that knowing one's student gains critical importance when one is working with ELLs; this includes knowing who they are, where they have come from, and what strengths they bring to the classroom. All ELLs are not alike; some might have had adequate formal schooling, while others might be long-term ELLs. Culturally Responsive Pedagogy (CRP), which has gained popularity in K-12 schools that include ethnically diverse students, is a pedagogy that could benefit many students in higher education, especially those who visit WCs. 


\section{What is Culturally Responsive Pedagogy?}

Until the 1970s, white middle-class culture, language, and values were regarded as the norm, and everything else, including the language, literacy, and culture of students of color, was perceived as inferior. The goal of deficit approaches, according to Paris (2012), was to "eradicate the linguistic, literacy, and cultural practices many students of color brought from their homes and communities, and to replace them with what were viewed as superior practices" (p. 93). Following the publication of Gloria Ladson-Billing's landmark article, Towards a Theory of Culturally Relevant Pedagogy, the abbreviations CRP (for Culturally Relevant Pedagogy or Culturally Responsive Pedagogy) and CRT (for Culturally Responsive Teaching) used synonymously, became ubiquitous in education research circles. Ladson-Billings called for "a culturally relevant pedagogy that would propose to do three things - produce students who can achieve academically, produce students who demonstrate cultural competence, and develop students who can both understand and critique the existing social order" (1995, p.474). Gay defined CRP as the use of "cultural characteristics, experiences, and perspectives of ethnically diverse students as conduits for teaching them more effectively" (2002, p. 106). Santamaria (2009) highlighted the powerful influence that CRP can have on students because it:

affirms students' cultures, viewing them as transformative and emancipatory strengths (rather than deficits);incorporates students' cultures in the teaching process, thus empowering them to take ownership of their learning; and leads to their increased participation in societal activities. (pp.226-227)

Fundamentally, culturally responsive teachers value the "funds of knowledge" that students bring with them (Roseberry, McIntyre, \& Gonzalez, 2001), understand and appreciate their diverse backgrounds, and respond to students' needs with cultural sensitivity. Because it is based on constructivism, collaboration is emphasized during the process of teaching and learning, and students are given opportunities to contribute to the instructional content (Callins, 2006; Gay, 2000; Irvine, 2001; Kea, Campbell-Whatley, \& Richards, 2006; Stroder, 2008; Wlodkowski\& Ginsberg, 1995).

\section{Culturally Responsive Pedagogy in Practice: Illustrative Examples}

There is a gap between college faculty members' and elementary school teachers' documented use of CRP (Donkor, 2011). Searches of multiple databases using the key words "CRP," "CRT," and "higher education" yielded between 19 and103 articles. This literature provided very few examples of what could be characterized as CRP, and there were no articles that explicitly described how CRP was used to provide international students with necessary support for academic writing. Descriptions, when provided, reflected changes in classroom procedures initiated by individual faculty (Mendelsohn, 2002; Ronesi, 2001), rather than changes in philosophy, content, or strategy within courses or across departments and divisions. Consistent with Donkor's (2011) observation, it was apparent that traditional and contemporary teaching, guided by a mono-cultural curriculum and the lecture method, were often devoid of references to cultural differences.

Database searches using the keywords "CRP,"“CRT," and "K-12 schools" yielded between 339 and 643 articles. A large proportion of those articles concerning college teaching related to the work faculty are doing to prepare pre-service and in-service teachers to work with diverse K-12 student populations. The majority of the studies that were qualitative in nature 
describe how CRP is being enacted by teachers in K-12 classrooms and the influence CRP had on diverse students' social and academic needs (Bonner, \& Adams, 2012; Gay, 2000; KellyJackson \& Jackson, 2011). This literature supports Lopez's (2011) argument that culturally relevant teaching practices do not happen by chance. The three K-12 examples presented below, in the absence of higher education examples, confirm that CRP "requires teachers to be critically aware and agentive in their classroom, drawing on relevant socio-cultural theories and creating their own purposeful practice" (Lopez, 2011, p.76).

Using a grounded theory case study approach Bonner and Adams (2012) researched the way Ms. Finley (see example 1) enacted CRP in her fifth grade mathematic classroom. They were able to develop a working theory of culturally responsive mathematics theory, which rests on the four interconnected, foundational cornerstones communication, knowledge, trust/relationships, and constant reflection/revision, which have implications for teachers who teach other content areas and writing center tutors.

Example 1. Ms. Finley's Mathematics Classroom. Ms. Finley's teaching was based on a strong command of mathematics content and pedagogy knowledge and knowledge of the community. Her students were placed at the center of her practice. To ensure that students received help at home she ran a night class for parents. Additionally, she visited students and families in the neighborhoods to gain insight into her students' lives and encourage parents to be involved in their children's education. Seamlessly, she wove the insights she gained through these interactions, along with personal anecdotes of challenges she faced as she tried to empower her students to become agents of social change.

Rejecting the deficit approach, she employed a variety of verbal and non-verbal communication techniques to engage and empower her students. Music, similar to that which students saw on Black Entertainment Television, became an integral part of mathematics lessons. Choral responses, similar to that which her students used in church, were used to reinforce concepts, and enhance student involvement. As a warm demander she cultivated a trusting relationship; she told students how much she cared, set high expectations for them, and helped them reach their goals. Her students taught her what was hip, and not hip. She reflected and revised her curriculum constantly; using both student-generated alternative approaches to explain troubling mathematics concepts and their impromptu ideas.

Using a case study approach Kelly-Jackson and Jackson (2011) studied the pedagogy of a sixth grade science teacher who taught at one of the four county schools referred to as the Corridor of Shame. Of the eight teachers who completed the questionnaire, Sammie's (pseudonym) pedagogy was representative of the literature on CRP. Additional data were collected through multiple sources both during and after school hours to highlight the ways in which Sammie embraced the notion of CRP. Example 2 provides a brief overview of Sammie's pedagogy.

Example 2. Ms. Sammie's Grade 6 Science Classroom. The school where Sammie taught, which included predominantly African American students, had been ranked below average in absolute rating for three years prior to the study. Sammie positioned herself as a learner and demonstrated a keen sense of purpose as a science educator. To actively engage students in the construction of knowledge and motivate them intrinsically, Sammie developed a 
curriculum around students' interests. She gave students an opportunity to dialogue about lessons and units, generate ideas, and set goals. The value she placed on collaborative learning was reflected in the way the furniture was arranged in groups, the learning spaces she created for exploration and hands-on work, the assignments she designed, and the expectation that each student fulfills a role that ensures group success.

Sammie demonstrated, in numerous ways, her commitment to learning from parents, the community, her colleagues, and students. She established a fluid relationship with her students beyond the science classroom by taking on the role of cheerleading coach. "She was firm, yet flexible about classroom expectations and helped students understand the meaning of consequences" (Kelly-Jackson \& Jackson, 2011, p.411). She encouraged students to hang out in her classroom on game night to keep them out of trouble and required 'cheer moms' to bring in snacks so students did not have a reason to leave.

The pedagogical approaches employed by teachers can help students develop cultural competence, critical consciousness and the ability to interrogate the discursive structures; skills needed now more than ever, given the social trends and demographic shifts. The third example, drawn from Lopez's (2011) case study, highlights the common elements of CRP and critical literacy, and how this was practiced by an English teacher in a heterogeneous and "truly multicultural" sub-urban, multiracial, multiethnic, multi-lingual and multi-faith 12 grade English classroom.

Example 3. Ms. Meriah's Grade 12 English Classroom. Concerned about the crossracial tensions and level of student engagement she witnessed in her classroom and school, Ms. Meriah, a teacher in Southern Ontario, Canada used CRP to re-conceptualize her 12 grade Writer's Craft class. She "took the students in her diverse multicultural classroom on a journey of deconstructing and reconstructing how they view different forms of poetry, knowledge that is privileged and not privileged, and their own understanding of people who do not look like them" (Lopez, 2011, p.76). Data sources included journals, classroom observations, and dialogues. Inquiry-group meetings were a source of data collection and analysis. In this safe learning space she formally and informally teased out and deconstructed her teaching with a critical friend.

Ms. Mariah engaged her sub-urban students in reading poetry written by urban youth. Students wrote their critiques in their journal. Students were asked to respond to the questions: "How did you feel while you were reading the poems? Were you able to relate to the experiences described? If so, how? If not, why not?" (p.83) and "How are they different from me? How are they like me? What do I need to learn? What do I need to unlearn?" (p.84). Deconstruction and critique of the poems in small and large groups gave them the opportunity to gain exposure to multiple perspectives as they examined the authors' position, their assumptions and biases, and their own experiences. Unaccustomed to talking about race and its impact on society so openly, the emotionally charged discussions were initially uncomfortable for many, especially the white students. As the discomfort dissipated students began to realize how this form of writing could be used to express issues they faced. Towards the end of the unit, students constructed performance poetry based on their own experiences. This form of poetry empowered students to verbalize the injustices in their own lives. This prompted some students to become involved in 
student councils so they could talk about these issues. Students' journal entries showed a growing awareness of "the other" and how oppression works in multiple ways.

As evident from the three illustrative examples presented above, a single formula does not exist; CRP is multidimensional in nature. A common ingredient is the belief that all students can learn; a willingness to modify curriculum, instruction, and assessment procedures to allow students to reach their potential; and commitment to social equity and justice.

\section{Writing Centers in America: A Culturally Responsive Supplemental Model}

WCs are places for ELLs to seek assistance outside formal courses. The benefits to ELLs who visit WCs would be maximized if the services offered there were grounded in CRP. The proposed model below describes the design of a supplemental program that would benefit all ELLs in general, and Chinese ELLs in particular.

\section{Target Population}

The supplemental program described in this section would be ideal for Chinese students who have moved to America to work on undergraduate and/or graduate degrees at Englishlanguage-dominant colleges and universities. Each of these students would typically have a mastery of learning in the Chinese language, a variety of rich personal and educational experiences, and a detailed knowledge of Chinese culture and history. Prior to coming to America, they would have learned English through "formal and metalinguistically-oriented" classroom instruction (Harklau et al., 1999). To gain admission into an American college or university, they each would have passed a Test of English as a Foreign Language (TOEFL) examination. Their test scores would have to meet or exceed university requirements. Therefore, they would have proven basic proficiency in spoken and written English.

\section{Design and Core Components of the Program}

Purpose of the Supplemental Program. The purpose of this supplemental program would be to provide culturally responsive assistance based on the characteristics and academic needs of Chinese ELLs in an English-language-dominant learning environment. This social and academic support would allow students to adapt more easily to different educational environments.

Tutors. Tutors would be university-employed Chinese graduate assistants with a high level of proficiency in spoken and written English and experiences similar to the targeted tutees, or university professors, or members of the community who would like to dedicate themselves to helping Chinese international students voluntarily. Tutors would have one-on-one long-term relationships with their tutees, instead of conferencing with different tutees every time; this would allow them to build a rapport with their assigned tutees and truly understand their tutees' individual and unique needs.

Training Provided to Tutors. Yancey (2002), through her analysis of logs maintained by graduate and undergraduate students enrolled in tutoring courses, found that recording and reflecting on data relating to tutors' verbal and nonverbal interactions with their tutees allows the tutors to create reflective spaces for "tutor-as-agent" and "tutor-as-learner." In her article, The 
Return of the Suppressed: Tutoring Stories in a Transitional Space, Welch (2002) explained how her analysis of tutors' stories often included a first story, the "theory" or "wish," and a second story, the "practice" or "reality." She also explained how "official stories of tutoring lose some of their officialness and how suppressed stories gain visibility" when both are examined as stories that bear further exploration (p.206). She recommended that the central focus should not be on the "language barrier" but the "barrier to imaging the range of concerns, interests, and abilities that tutees bring." Therefore, prior to working with ELLs, tutors should be taught how to maintain and use logs for reflective purposes and how to make sense of the conflicting stories embedded in their reflections. Reflecting on this data would allow them to notice particularities, differences, and patterns in not only their tutees' behaviors, but also their own. They would be taught how to use the data to understand their growth, form their identities as tutors, see the other in their tutees, and foster tutorial agency.

Instead of focusing on basic interpersonal communication skills that Cummins (1981) called "surface" manifestations of language, including technical features like pronunciation,

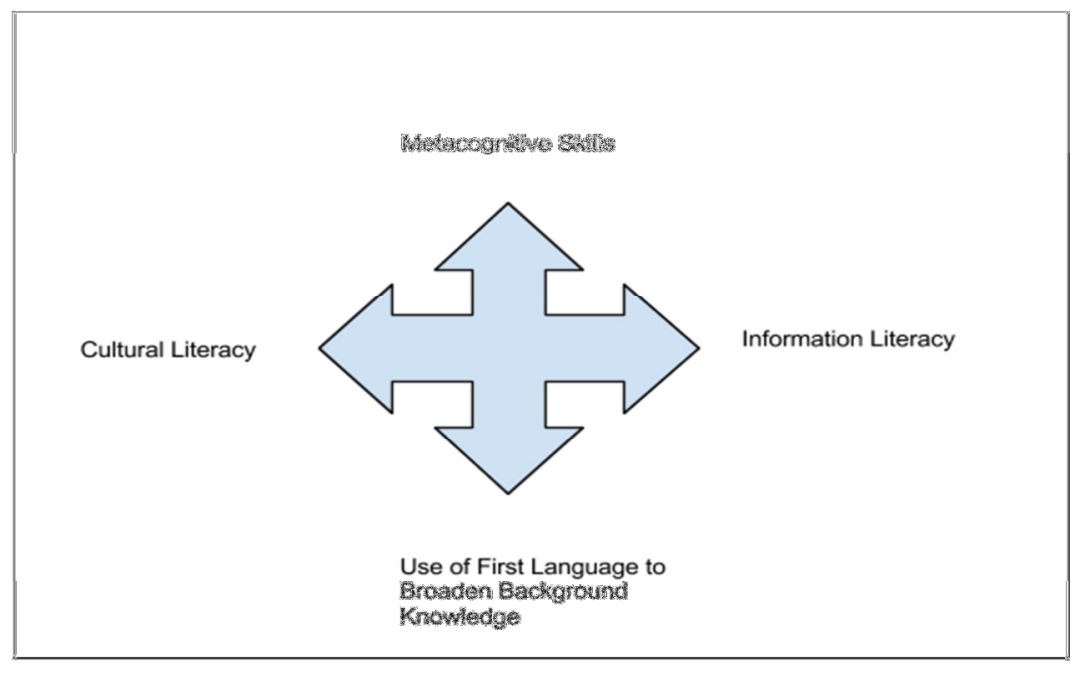

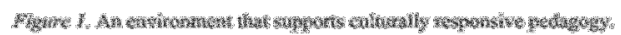
grammar, spelling, and basic vocabulary, tutors should be trained to create learning environments that support CRP and taught how to provide tutees with in-depth assistance in the four components reflected in Figure 1, namely, use of their first language to broaden background knowledge, cultural literacy, information literacy, and metacognitive skills.

\section{Use of First Language to Broaden Background Knowledge.}

Weaver and Jackson (2011) found that two major difficulties in academic writing for ELLs are understanding subject content in English and expressing their understanding of the content in English. Prior knowledge is a significant factor that affects students' understanding of new information (Ormrod, 2008). It is also an essential predictor of students' success with reading comprehension (Fisher \& Frey, 2009; Vaughn \& Bos, 2012). It is a misconception that ELLs need to read everything in English to improve their learning. For language learners with limited proficiency in English, reading nothing but English texts only increases barriers to learning and does not help with writing.

Krashen, who has done extensive work in second language learning, found that instruction in students' native languages aids comprehension and language development (2000). Cummins (1981), distinguishing between social and academic language proficiency, maintained that academic language proficiency transfers from one language to the next. Research done over the last two decades has confirmed that this continues to be true: students' second-language writing proficiencies positively correlate to their first language proficiencies, and literacy skills can be transferred across languages (Rodriguez \& Gomez, 2008; Zhang, 2008). Tutors should 
encourage Chinese ELLs to read relevant content in Chinese first, to gain conceptual understanding, and then read the information in English. Understanding the content in their native language will help them to connect to the content in English more easily. This will make it easier for them to write.

Using a tutee's first language to help with second-language learning should only be used as a transition strategy. This approach should be employed in earlier stages of learning in new language environments, because it is faster for students to acquire knowledge in their first languages. Gradually students should be encouraged to engage in authentic English reading. The more knowledge a person has, the easier he/she will be able to make connections to new information. Kobayashi and Rinnert (1992) found that skill in speaking English had a greater impact on writing quality than did knowledge of English grammar. Thus, ELLS should also be encouraged to practice speaking English.

Translating English, instead of freely writing in English, is commonly used in a foreign language learning environment, especially in China. This approach might work for students with limited proficiency that find it difficult to think in English, but it has limited benefits for students with higher levels of proficiency in English (Kobayashi \& Rinnert, 1992). To learn how to think in English, students need considerable practice. Tutors should be taught how to engage tutees in free reading, which has been identified as an effective approach (Lee, 2005) to developing a deeper understanding of the English language.

2. Cultural Literacy. Writing in another language is a process of cultural learning (X. Li, 2007), as well as a process of personal growth. To bridge the gap in knowledge between Chinese students and their American counterparts, tutors should provide Chinese ELLs with information about Western thinking and writing, the American educational system, Western learning styles, and Western values. This will help them to understand the classroom environment, instructor and peer expectations, and the individualistic learning paradigm that prevails at American universities. It would also help them to adapt to Americans' perceptions of "appropriate" English writing, logic and rhetoric.

3. Information Literacy. Academic writing is a complex process of discovery "that involves brainstorming, multiple drafting, feedback practices, revision, and final editing" (Zhang, 2008, p. 96). Academic writing is also influenced by a student's information literacy (Lin, 2007), or the skills of locating, evaluating, and using information effectively, which is essential for people living in the Information Age (Association of College and Research Libraries, 2000). It is also an essential part of independent learning, and it is especially important for college students who work on multiple assignments simultaneously. They need to learn how to skim, scan, and quickly evaluate written text in order to acquire knowledge that relates to different content areas.

Librarians at American universities typically engage students in information literacyrelated activities. Additionally, some instructors integrate information literacy into their English as a Second Language (ESL) courses to meet the unique needs of ELLs as well (Conteh-Morgan, 2001). A culturally responsive program for Chinese ELLs should pay special attention to information literacy by highlighting its value (Lin, 2007). Information literacy skills should be taught explicitly to facilitate a deeper understanding of the concepts taught in students' classes. Students enrolled in such as supplementary program should be taught how to gain access to university resources associated with their learning, including online and physical library resources, and how to identify and use resources when involved in different writing projects. 
They should also be taught basic studying skills, like how to identify main ideas or topic sentences, an approach commonly used with English texts, but not with Chinese texts.

4. Metacognitive Skills. Metacognition deals with knowledge of one's own learning and thinking, as well as processes to enhance learning (Ormrod, 2008). Metacognition, as it relates to literacy development, aids individuals in identifying personal strengths and weaknesses when learning and writing in another language. Research has shown that metacognition is one of the essential factors that influence students' second-language learning and proficiency in secondlanguage writing (Devine, Railey, \&Boshoff, 1993; Kasper, 1997; Vandergrift, 2005; Yu \& He, 2010).

Familiarizing students with information about cultural differences in thinking will provide them the opportunity to further develop their metacognitive skills. Additionally, the program should provide students with instruction that allows them to become aware of their own processes of learning and writing. They should be taught how to plan to improve their writing accordingly. Instruction should target development of knowledge and skills in five areas: 1) knowing effective and ineffective learning strategies through self-evaluation; 2) being aware of one's own capabilities and making realistic goals that can be accomplished; 3) making plans with learning tasks that are likely to effectively achieve goals; 4) monitoring one's own learning processes and progress; and 5) self-motivation (Anderson, 2002; Ormrod, 2008).

Format of Tutoring Sessions. Tutees should be offered both group instruction and individual tutoring sessions. The four components presented in Figure 1 can be seamlessly integrated into both. Initially, tutors should meet with their tutees for four hours per week, and the number of contact hours will be reduced as tutees gain confidence and English proficiency. For the first few sessions, in groups, tutors should focus on cultural literacy and information literacy. When appropriate, tutors should use Chinese to explain complicated concepts and to provide examples from Chinese media and popular culture to help tutees connect more easily with the new material. This bilingual interaction between tutors and tutees will limit the amount of frustration that tutees face with tutors who are NES.

During individual sessions, tutees should identify their individual difficulties or needs as they relate to learning and academic writing. Tutees can then be taught how to interpret the expectations outlined in syllabi, writing requirements, and rubrics; provided with opportunities to ask about the university, American culture, the educational system, and available resources; and taught how to organize this information in culturally relevant ways. Tutees should be encouraged to contact their tutors for additional assistance.

\section{Potential Obstacles to Implementation of the Proposed Supplemental Program}

The proposed supplemental program, which was developed in response to needs expressed by Chinese ELLs, requires that the tutor be of the same racial and linguistic background as the tutee. WC directors who wish to start a supplemental program should recognize and address some of the obstacles listed below.

1. The biggest challenge to successful implementation of this supplemental program is overturning the conscious and unconscious ways in which ethnocentric practices continue to prevail at institutions of higher education. It will take a lot more than good intentions to combat 
the negative sentiments concerning immigrants that continue to be rampant in small university towns (Foner, 2005).A systemic approach is needed to change "the largely monocultural character of public discourse in education" (Sawir, Marginson, Deumert, Nyland, \&Ramia, 2008) that prevails at many Western institutions.

2. WCs are often staffed with NES tutors that are predominantly white. Replacing NES tutors with Chinese ELL tutors who are proficient in English could have political ramifications at WCs but also within English Departments, who often expect WCs to hire students enrolled in their programs.

3. It would be difficult to project the number of Chinese international students who are both proficient in English and willing to work with Chinese ELLs. WC directors would have to reach out to program coordinators across disciplines and International Student Offices to identify and recruit Chinese students with high levels of proficiency.

4. Recruiting Chinese ELLs to serve as tutors and requiring that they establish long-term relationships with tutees could prove cost-prohibitive. Legally, international students are only allowed to work on campus for 20 hours a week. WC directors can reach out to program directors to identify Chinese students who are proficient in English and offer these students fulltime and part-time graduate assistantships.

5. Chinese ELLs who are unaware of the literature that documents the benefits of using firstlanguage instruction to promote second-language acquisition might perceive that they will grasp English more quickly if they are teamed with NES tutors (Huo, Chng\& Ma, 2006). This obstacle can easily be addressed in the orientation programs offered to newly enrolled international students by the International Student Offices at the beginning of each semester.

\section{Conclusions and Recommendations}

WCs serve the academy's academic mission in ways that are different from the traditional classroom approach. That which makes them different also gives them the opportunity to innovate and experiment across disciplinary and organizational borders (Carino, 2002). By situating the work of WCs as integral to the institution's mission, WC directors can challenge the negative perceptions associated with WCs. Carino (2002) suggests that "directors must inform without confusing, must educate without condescending, must promise without bluffing, must assert without offending, and must offer help without promising civility" (p. 92).

Empirical and best practice research cited in this paper shows that, while WCs successfully meet the needs of NES students who struggle with academic writing, they do not always meet the needs of Chinese students who make up the largest group of international students at American universities. Directors of WCs, staff, and tutees need to recognize that Chinese students' writing styles are influenced by factors, like the Chinese educational system, social values, and life philosophy, which are significantly different from those in American culture. WC directors who immerse themselves in best practice and empirical literature that relates to ELLs' needs and alternative tutoring approaches will be better equipped to provide services that meet the needs of ethnically, linguistically, and culturally diverse students' unique needs.

The research cited in this paper establishes the need for descriptive and evaluative 
research relating to existing pedagogical practices at WCs and the extent to which these reflect institutional commitment to diversity. This research, when coupled with research on WC administration, for which there is also a need (Harris, 2002), will allow WCs to serve these subpopulations appropriately.

WCs are microcosms of the changes and redefinitions that the academy is undergoing, and therefore WC directors need to become agents of change. Evaluative research will allow WCs to determine if the non-directive approach that is currently being offered to Chinese ELLs is actually working. If not, non-directive alternative approaches described by Shamoon and Burns (1995) or other supplemental programs which are grounded in CRP, like the one described in this paper, should be explored. Recognizing and overcoming each of the obstacles outlined in this paper would be important first steps toward creating culturally responsive and socially relevant WCs.

\section{REFERENCES}

Anderson, N. J. (2002). The role of metacognition in second-language teaching and learning. ERIC Digest. Retrieved fromhttp://www.eric.ed.gov/PDFS/ED463659.pdf

Andrade, M. S. (2006). International students in English-speaking universities: Adjustment factors. Journal of Research in International Education, 5(2), 131-154. doi: $10.1177 / 1475240906065589$

Association of College and Research Libraries. (2000). Information literacy competency standards for higher education. Retrieved fromhttp://www.ala.org/acrl/sites/ ala.org.acrl/files/content/standards/standards.pdf

Ballard, B., \& Clanchy, J. (1991). Assessment by misconception: Cultural influences and intellectual traditions. In L. Hamp-Lyons (Ed.), Assessing second language writing in academic contexts (pp. 19-35). Norwood, NJ: Ablex.

Banks, J. A. (2010). Series forword. In J. A. Banks (Ed.), The light in their eyes (10th anniversary ed., pp. ix-xii). New York, NY: Teachers College Press.

Bartlett, T., \& Fischer, K. (2011). China conundrum. Retrieved fromhttp://www.nytimes.com/2011/11/06/education/edlife/the-chinaconundrum.html?pagewanted=all\&_r=0

Blakely, R. (1995). The English Language Fellows Program. College ESL, 5(2), 1-20.

Bonner, E. P. \& Adams, T. L. (2012). Culturally responsive teaching in the context of Mathematics: A grounded theory case study. Journal of Mathematics Teacher Education, $15,25-38$.

Brendel, C. (2012). Tutoring between languages with comparative multilingual tutoring. Writing Center Journal, 32(1), 78-91.

Cai, G. (1993). Beyond“bad writing”: Teaching English composition to Chinese ESL students. Paper presented at the Conference on College Composition and Communication, San Diego,CA.

Callins, T. (2006). Culturally responsive literacy instruction. Teaching Exceptional Children, $39(2), 62-65$.

Carino, P. (2002). Reading our own words: Rhetorical analysis and the institutional discourse of writing centers. In P. Gillespie, A. Gillam, L. F. Brown, \& B. Stay (Eds.), Writing centerresearch: Extending the conversation (pp. 93-112). Mahwah,NJ: Lawrence Erlbaum Associates. 
Carson, J. G., \& Nelson, G. L. (1996). Chinese students' perceptions of ESL peer response group interaction. Journal of Second Language Writing, 5(1), 1-19.

Conteh-Morgan, M. E. (2001). Empowering ESL students: A new model for information literacy instruction. Research Strategies, 18(1), 29-38. doi: 10.1016/S0734-3310 (02)00064-2

Cortazzi, M., \& Jin, L. (1996). Cultures of learning: Language classrooms in China. In H. Coleman (Ed.), Society and the language classroom (pp. 169-206). Cambridge, UK: Cambridge University Press.

de Araujo, A. A. (2011). Adjustment issues of international students enrolled in American colleges and universities: A review of the literature. Higher Education Studies, 1(1), 2-8. doi: 10.5539/hes.v1n1p2

Devine, J., Railey, K., \& Boshoff, P. (1993). The implications of cognitive models in L1 and L2 writing. Journal of Second Language Writing, 2, 203-225.

Donkor, A. K. (2011). Higher education and culturally responsive teaching: A way forward. The Journal of Multiculturalism in Education, 7, 1-29.

Eckstein, L.K., Kalaydjian, K.S., Miranda, A., Mitchell, D. A., Mohamed, A., Smith-Palinkas, B, York, J.,\& Zollner, L.E. (2003). People's Republic of China.In J.Flaitz (Ed.), Understanding your international students: An educational, cultural, and linguistic guide (pp. 100-110). Ann Arbor, MI: University of Michigan Press.

Elander, J., Harrington, K., Norton, L., Robinson, H., \& Reddy, P. (2006). Complex skills and academic writing: A review of evidence about the types of learning required to meet core assessment criteria. Assessment \& Evaluation in Higher Education, 31(1), 71-90. doi: $10.1080 / 02602930500262379$

Fisher, D., \& Frey, N. (2009). Background knowledge: The missing piece of the comprehension puzzle. Portsmouth, NH: Heinemann.

Foner, N. (2005).In a new land: A comparative view of immigration. New York, NY: NYU Press. Retrieved from http://books.google.com/books?

Fox, H. (1994). Listening to the world: Cultural issues in academic writing. Urbana, IL: National Council of Teachers of English.

Gay, G. (2000). Culturally responsive teaching: Theory, research, practice. New York, NY: Teachers College Press.

Gay, G. (2002). Preparing for culturally responsive teaching. Journal of Teacher Education, 53(2), 106-116.

Gillam, A. (2002). The call to research:Early representations of writing center research. In P. Gillespie, A. Gillam, L. F. Brown, \& B. Stay (Eds.), Writing center research: Extending the conversation (pp.3-21). Mahwah, NJ: Lawrence Erlbaum Associates.

Harklau, L., Losey, K. M., \& Siegal, M. (1999). Linguistically diverse students and college writing: What is equitable and appropriate? In L. Harklau, K. M. Losey,\& M. Siegal (Eds.), Generation 1.5 meets college composition: Issues in the teaching of writing to U.S.-educated learners of ESL (pp. 1-14). Mahwah, NJ: Lawrence Erlbaum Associates.

Harris, M. (2002).Writing center administration: Making local, institutional knowledge inour writing centers. In P. Gillespie, A. Gillam, L. F. Brown, \& B. Stay (Eds.), Writing center research: Extending the conversation(pp. 77-92). Mahwah, NJ: Lawrence Erlbaum Associates.

Hofstede, G. (1980). Culture's consequences. Beverly Hills, CA: Sage.

Huang, J., \& Brown, K. (2009). Cultural factors affecting Chinese ESL students' academic learning. Education, 129(4), 643-653. 
Huo, Q., Chng, E. S., \& Ma, B. (Eds.). (2006). Proceedings from the ISCSLP 2006: 5th International Symposium, ISCSLP 2006.Singapore: Springer.

Hyland, K. (2003). Second language writing. Cambridge, England: Cambridge UP.

Institute of International Education. (2012). 2012 Open Doors Report. Retrieved fromhttp://www.iie.org/en/Research-and-Publications/Open-Doors

Institute of International Education. (2013). Open Doors Report on International Educational Exchange. Retrieved from http://www.iie.org/opendoors.

Irvine, J. J. (2001). The critical elements of culturally responsive pedagogy: A synthesis of the research. In J. J. Irvine, \& B. J. Armento (Eds.), Culturally responsive teaching: Lesson planning for elementary and middle grades (pp. 2-17). New York, NY: McGraw-Hill Higher Education.

Kasper, L. (1997). Assessing the metacognitve growth of ESL student writers. Retrieved fromhttp://www.tesl-ej.org/wordpress/issues/volume3/ej09/ej09a1/

Kea, C., Campbell-Whatley, G., \& Richards, H. (2006). Becoming culturally responsive educators: Rethinking teacher education pedagogy. Retrieved from http://www.nccrest.org/Briefs/Teacher_Ed_Brief.pdf

Kelly-Jackson, C. P. \& Jackson, T.O. (2011). Meeting their fullest potential: The beliefs and teaching of a culturally relevant sciene teacer. Creative Education, 2(4), 408-413.

Kobayashi, H., \& Rinnert, C. (1992). Effects of first language on second-language writing: Translation versus direct composition. Language Learning, 42, 183-215. doi: 10.1111/j.1467-1770.1992.tb00707.x

Ladson-Billings, G. (1995). Towards a theory of culturally relevant pedagogy. American Education Research Journal, 32, 465-491.

Lee, S. (2005). How robust is in-class sustained silent reading? An SSR program for non-English majors. Studies in English Language and Literature, 15, 65-76.

Li, J. (2011). Cultural foundations of learning: East and west. New York, NY: Cambridge University Press.

Li, X. (2007). Identities and beliefs in ESL writing: From product to processes. TESL Canada Journal, 25(1), 41-64.

Lin, M. (2007). How helping Chinese ESL college students write research papers can teach information literacy. Journal of East Asian Libraries, 141(1), 6-11.

Lopez, A. E. (2011). Culturally relevant pedagogy and critical literacy in diverse English clasrooms: A case study of a secondary English teacher's activism and agency. English Teaching: Practice and Critique, 10(4), 75-93.

Matsuda, P. K., Fruit, M., \& Lamm, T. L. B. (2006). Second-language writers and writing program administrators. WPA: Writing Program Administration - Journal of the Council of Writing Program Administrators, 30(1/2), 11-14.

Mendelsohn, D. (2002). The "Lecture Buddy" Project: An experiment in EAP listening comprehension. TESL Canada Journal, 20(1), 64-73.

Mohan, B. A., \& Lo, W. A. (1985). Academic writing and Chinese students: Transfer and developmental factors. TESOL Quarterly, 19, 515-534. doi: 10.2307/3586276

Nakamaru, S. (2010). Lexical issues in writing center tutorials with international and USeducated multilingual writers. Journal of Second Language Writing, 19(2), 95-113.

Nisbett, R. E., Peng, K. P., Choi, I., \& Norenzayan, A. (2001). Culture and systems of thought: Holistic versus analytic cognition. Psychological Review, 108(2), 291-310. doi: 10.1037//0033-295x.108.2.291 
Ormrod, J. E. (2008). Human learning (5th ed.). Upper Saddle River, NJ: Pearson Education.

Paris, D. (2012). Culturally sustaining pedagogy: A needed change in stance, terminology, And practice. Educational Researcher, 41(3), 93-97.

Powers, J. K. (1993). Rethinking writing center conferencing strategies for the ESL writer. Writing Center Journal, 13(2), 39-47.

Rodby, J. (2002).The subject is literacy: General education and the dialectics of power and resistance in the writing center. In P. Gillespie, A. Gillam, L. F. Brown, \& B. Stay (Eds.),Writing center research: Extending the conversation (pp.203-220). Mahwah, $\mathrm{NJ}$ :Lawrence Erlbaum Associates.

Ronesi, L. (2001). Training undergraduates to support ESL classmates: The English Language Fellows Program. TESOL Journal, 10(2-3), 23-27.

Salamonson, Y., Everett, B., Koch, J., Andrew, S., \& Davidson, P. M. (2008). English language acculturation predicts academic performance in nursing students who speak English as a second language. Research in Nursing \& Health, 31(1), 86-94.

Salamonson, Y., Koch, J., Weaver, R., Everett, B., \& Jackson, D. (2010). Embedded academic writing support for nursing students with English as a second language. Journal of Advanced Nursing, 66(2), 413-421. doi: 10.1111/j.1365-2648.2009.05158.x

Santamaria, L.J. (2009). Culturally responsive differentiated instruction: Narrowing gaps between best pedagogical practices benefiting all learners.Teachers College Record,111(1), 214-247.

Sawir, E., Marginson, S., Deumert, A., Nyland, C., \& Ramia, G. (2008). Loneliness and international students: An Australian study. Journal of Studies in International Education, 12(2), 148-180.

Senyshyn, R. M., Warford, M. K., \& Zhan, J. (2000). Issues of adjustment to higher education: International students' perspectives. International Education, 30(1), 17-35.

Severino, C., \& Deifell, E. (2011). Empowering L2 tutoring: A case study of a second language writer's vocabulary learning. Writing Center Journal, 31(1), 25-54.

Shei, C. (2005). Integrating content learning and ESL writing in a translation commentary writing aid. Computer Assisted Language Learning, 18(1-2), 33-48.

Stroder, M. E. (2008). Effects of culturally responsive teaching practices on the literacy learning of Latino students. Masters Theses \& Specialist Projects. Paper 29. Retrieved from http://digitalcommons.wku.edu/theses/29

Thonus, T. (2004). What are the differences:Tutor interactions with first- and second-language writers. Journal of Second Language Writing, 13(3), 227-242. doi: 10.1016/j.jslw.2004.04.012

Triandis, H. C. (Ed.). (1980). Handbook of cross-cultural psychology. Boston: Allyn \& Bacon. Vandergrift, L. (2005). Relationships among motivation orientations, metacognitive awareness, and proficiency in L2 listening. Applied Linguistics, 26(1), 70-89.

Vaughn, S., \& Bos, C. S. (2012). Strategies for teaching students with learning and behavior problems (8th ed.). Upper Saddle River, NJ: Pearson Education.

Wang, L. (2012). Behind the curtain: A critical view of theory and practice of tutoring international English language learners at university writing centers. (Ph. D Dissertation), Indiana University of Pennsylvania, USA. Available from ProQuest Social Sciences Premium Collection (Order No.AAI3505110) 
Weaver, R., \& Jackson, D. (2011). Evaluating an academic writing program for nursing students who have English as a second language. Contemporary Nurse: A Journal for the Australian Nursing Profession, 38(1/2), 130-138. doi: 10.5172/conu.2011.38.1-2.130

Weigle, S. C., \& Nelson, G. L. (2004). Novice tutors and their ESL tutees: Three case studies of tutor roles and perceptions of tutorial success. Journal of Second Language Writing, 13(3), 203-225. doi: 10.1016/j.jslw.2004.04.011

Welch, N. (2002). The return of the suppressed: Tutoring stories in a transitional space. In P.Gillespie, A. Gillam, L. F. Brown, \& B. Stay (Eds.), Writing center research: Extending the conversation (pp.203-220). Mahwah, NJ: Lawrence Erlbaum Associates.

Wen, Q. (2006). On the cultivation of higher-order thinking skills of postgraduate English majors. Academic Degrees \& Graduate Education, 10, 29-34.

Williams, J. (2002). Undergraduate second language writers in the writing center. Journal of Basic Writing, 21(2), 73-91.

Williams, J., \& Severino, C. (2004). The writing center and second language writers. Journal of Second Language Writing, 13(3), 165-172. doi: 10.1016/j.jslw.2004.04.010

Williams, J. D. (2011). Help-seeking, self-efficacy, and writing performance among college students. Journal of Writing Research, 3(1), 1-18.

Wlodkowski, R., \& Ginsberg, M. B. (1995). A framework for culturally responsive teaching. Educational Leadership, 53(1), 17-21. (EJ511715)

Writing Center Research Report, 2007-2008. Louisville, KY: International Writing Centers Association. Retrieved on December 31, 2011, from http://casebuilder.rhet.ualr.edu/wcrp/

Yancey, K. B. (2002).Seeing practice though their eyes: Reflection as teacher. In P. Gillespie, A. Gillam, L. F. Brown, \& B. Stay (Eds.), Writing centerresearch: Extending the conversation (pp.75-90). Mahwah,NJ: Lawrence Erlbaum Associates.

$\mathrm{Yu}, \mathrm{H} .$, \& He, Z. (2010). A review of the empirical research on metacognition in ESL/EFL writing. International Forum of Teaching \& Studies, 6(2), 34-40.

Zhang, J. (2008). A comprehensive review of studies on second language writing. HKBU Papers in Applied Language Studies, 12, 89-123.

\section{About the Authors:}

CRYSTAL MACHADO is Associate Professor in the Department of Professional Studies in Education at Indiana University of Pennsylvania (IUP), where she works with pre-service and inservice teachers and administrators. Her research interests include multicultural and global education, reflective practice, innovative web-based technology, mentoring, and organizational change. E-mail: cmachado@iup.edu

PEIZHEN WANG is a Chinese international student in her fourth year of doctoral study in the Department of Professional Studies in Education at Indiana University of Pennsylvania. Her program is Curriculum \& Instruction. Her interests lie in multicultural education and teaching/learning strategies. E-mail: thlr@iup.edu 